YAK 620.9
DOI. $10.17747 / 2618-947 X-2019-1-36-45$

\section{Internationalization Strategies of Russian non-energy companies}

ABSTRACT

Financial University under the Government of the Russian Federation

The article is devoted to the generalization and descriptive analysis of foreign market entry strategies used by Russian non-energy companies. According to the research results, in most cases, the companies use either the replication strategy of offering a standardized product in all countries, or a strategy of limited adaptation products by local business units to local conditions. In addition,
assesses the impact of the liability of foreignness effect on internationalization process of Russian non-energy companies.

KEYWORDS:

internationalization strategies, Russian non-energy companies, liability of foreignness, competitive advantages.

FOR CITATION:

Nalbandyan G.G. Internationalization Strategies of Russian non-energy companies. Strategic Decisions and Risk Management 2019;10(1):36-45. DOI: 10.17747/2618-947X-2019-1-36-45

\section{Стратегии интернационализации российских компаний несырьевого сектора Экономики \\ г.Г. Налбандян} ' ФГОБу ВО «Финансовый университет

\section{АННОТАЦИЯ}

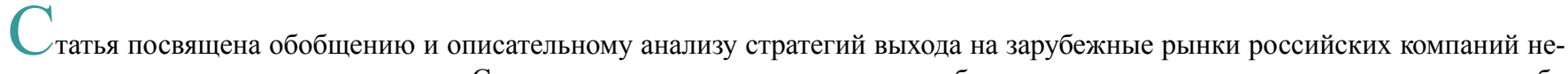
энергетических секторов экономики. Согласно результатам исследования, в большинстве случаев компании используют либо стратегию тиражирования, предлагая стандартизированный продукт во всех странах, либо стратегию ограниченной адаптации иностранца» на процесс интернационализации российских компаний неэнергетических секторов экономики.

КАЮЧЕВЫЕ САОВА:

стратегии интернационализации, российские неэнергетические компании, бремя иностранца, конкурентные преимущества.

\section{АИЯ ЦИТИРОВАНИЯ:}

Налбандян Г. Г. Стратегии интернационализации российских неэнергетических компаний // Стратегические решения и риск-менеджмент. 2019. T. 10. № 1. С. 36-45. DOI: 10.17747/2618-947X-2019-1-36-45

\section{INTRODUCTION}

The current state of the export activities of the Russian Fedration is characterized by a high share of commodity exports, which is about two-thirds of the total exports. Russia's exports for three quarters of 2018, according to the Russian Federal $\mathrm{Cu}$ toms Service, amounted to $\$ 325.6$ billion (Figure 1), non-energy exports increased to $\$ 105.3$ billion according to the REC's estimates. The growth of total exports compared to 3 quarters of 2017 was $28 \%(+71.3$ billion dollars), the growth of non-energy exports and for non-energy exports are recorded for the eigh hand the ninth quarter in a row. At the same time, the quarterly growth rate of total exports for seven quarters does not fall below $20 \%$. The main contribution to the increase in total exports was made by fuel ( $77 \%$ of cumulative growth) and metals $(10 \%)$. In non-energy exports the main contributors in growth were metal products $(44 \%)$, food $(23 \%)$, chemical products $(15 \%)$ and woo and paper products $(11 \%)$.

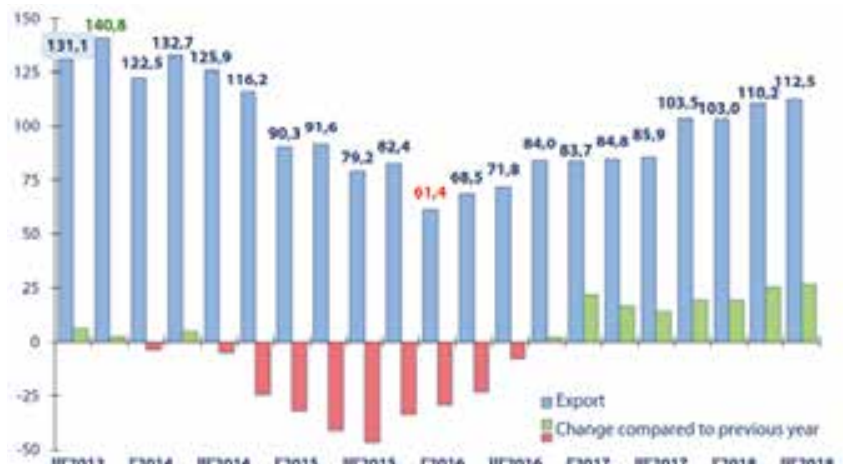

Figure 1. Dynamics of Russian exports, billion dollars'

In the structure of non-energy exports of Russia, the overwhelming majority steadily fall on 5 product groups, primarily metal products, engineering products, chemical goods and foodstuffs, and also paper and paper products. For 3 quarters of 2018 , their exports were characterized by the following values:

- Metal products $-\$ 31.7$ billion, $30.1 \%$

- engineering products $-\$ 20.3$ billion, $19.3 \%$

chemical goods $-\$ 19.8$ billion, $18.8 \%$

food - $\$ 16.4$ billion, $15.5 \%$

- wood and paper goods $-\$ 8.64$ billion, 8.2\% (Figure 2). Precious metals and stones have a notable weight in the (xport structure $\$$

various industrial products $-\$ 1.57$ billion, $1.5 \%$; - Class, ceramics, stone products $\$ 1.24$ billion, $12 \%$ - textiles, clothing, shoes $-\$ 0.92$ billion $0.9 \%$ - non-food agricultural products $-\$ 0.59$ billion, $0.6 \%$. The highest weight in non-energy exports of Russia for 3 quarters of 2018 were semi-finished unalloyed steel, whea (5.7\% each), aluminum and its alloys (3.6\%), sawn timber $(3.2 \%)$, refined copper $(2.9 \%)$, metals of the platinum grou $(2.5 \%)$, hot-rolled non-alloyed sheet metal $(2.4 \%)$ and mixed fertilizers (2.3\%), as well as aircraft. Nitrogen fertilizers (1.9\%), frozen fish $(1.7 \%)$, cast iron $(1.5 \%)$, turbo engines and gas turines $(1.4 \%)$, nickel $(1.3 \%)$, synthetic rubber and potash fertilizers $(1.2 \%$ each $)$

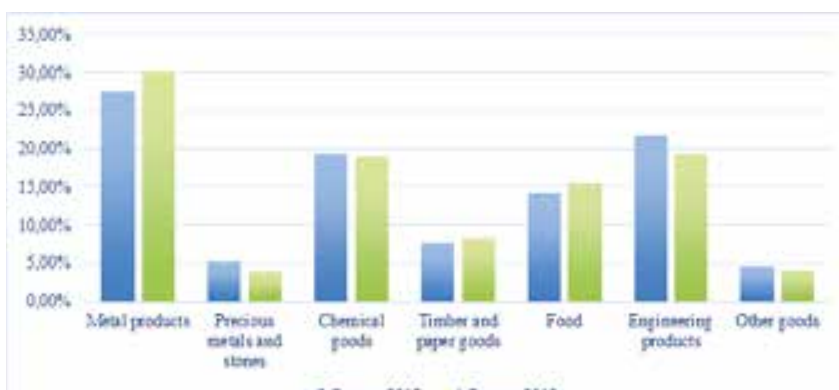

Figure 2. Russinn non-enegy non-commodity export, \%2

So, the internationalization of Russian companies becomes one of key conditions for the successful growth and developmen one of key conditions for the successful growth and development Tsukanova, 2013; Uvarov, 2013; Bukhvalov, Alekseeva, 2015; Katkalo, Medvedev, 2011; Knight, Liesch, 2016; Rugman, Verbeke, 2004; Tseng, Tansuhaj, Hallagan et al., 2007; Trachuk, Linder, 2018 and others).

Drivers of internationalization are opportunities for companies to diversify their activities, expanding their geographic presence, access to resources and markets of other countries, commercialization of innovations, and so on. At the same time, many studies confirm the positive relationship between entering the internation markets and increasing the effectiveness of its activities (Barnard 2010; Gammeltoft, Filatotchev, Hobdari, 2012; Mihailova, Panbratov, 2012; Trachuk, Linder, 2018), and in some works, intern-

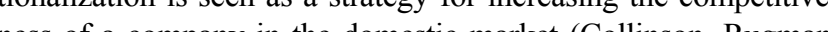
2007: L

In this context, the aim of the current article is a synthes

and descriptive analysis of interntionalization strategies used by Russian non-energy companies.

2. CLASSIFICATIONS

OF INTERNATIONALIZATION

STRATEGIES

In most studies (see, for example, Katkalo, Medvedev, 2011) two groups of factors causing the company's competitive advantages in foreign markets are identified: the advantages both due to the country characteristics and the specific characteristics of the company itself.

The country's advantages characterize its political, economic, egal, financial infrastructure, the skill level of the labor force, cultural traditions, availability of resources, etc. However, there are studies on the specific benefits of working in countries with growing markets (see, for example, Ramamurti, 2009).

At he sacts 
specific advantages or key competencies. These include product, process and management innovations, knowledge, brand, the ability of companies to work in growing markets. The pape (Ramamurti, 2009) indicated such a specific advantage for companies from countries with developing economies as government.
support

To classify the strategies used by companies to access ex2005 ), according to which the strategy is determined by the inter$2005)$, according to which the strategy is determined by the inte-
action of country-specific advantages and firm-specific advantages (FSA). The combination of "strong CSA - weak FSA" shows the place of oil companies and/or companies from mature industries, oriented to the external market. As applied to Russian practice, all companies from the commodity sectors, as well as large companies operating in the metallurgical, chemical, etc., fall into this square. The "weak CSA - strong FSA" square characterizes companies with strong brands and with developed ability to adap products to local market demands. For such companies, loca market conditions are not decisive. There aren't yet large Russia companies that meet hese conditions.

Barlet and Goshal (Harzing, 2000) classify strategies for accessing external markets according to the degree to which for integration to run a business, starting from replication, wee there is no need to take into account local conditions of activity and a high degree of integration, transnational, characterized by a high degree of need for local business conditions and integration. Jennet and Hennessey (Jeannet, Hennessey, 2004) develop a classification of strategies based on market-orientation and identify intra-national (ethnocentric), regional (regional-centric),

multinational (polycentric) and global (geocentric) strategies.

Depending on the level of risk that companies conduct for-

eign operations in the work of Finkelstein, Harvey and Lawto

Finkelstein, Harvey, Lawton, 2007), strategies are considered:

"Expand the horizons", involving the rapid expansion of

the company to foreign markets on the basis of products

markets (the least risky strtans)?

"Business model changes" is an expansion strategy by

"Bansforming the business model of a company that does

not affect its main product;

- "From lagging behind into leaders", gaining a leadership

position due to a change in the management paradiom and

the formation of a new strategy,

"Taking by storm" is a breakout strategy when new unknown

companies become market leaders for several years.

Works over the past two years (for example, Kotler, Berge Bickhoff, 2010; Knight, Liesch, 2016; Cerrato, Crosato, Depperu, 2016) suggest classifications of strategies based on the company's behavioral aspects in the external market. For example, it proposes a classification of strategies based on the degree of portfolio diversification, consolidation through mergers and acquisitions, the formation or partnerships and networks, as well as

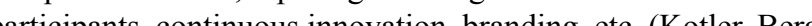
participants, continu.
er, Bickhoff, 2010).

Knight and Liesch (Knight, Liesch, 2016) consider the classification of internationalization strategies according to the degree of succession in entering foreign markets, and it is proposed to consider companies depending on the type of their internationalization: market-oriented (Marketer), investment-oriented (Investor), network enterprises (Networker), enterprises that have little Crosato, Depperu, 2016).

3. THE CAUSES OF LIABILITY

\section{OF FOREIGNNESS}

There is ample empirical evidence in the literature that comg foreign markets experience a range of difficultie that local firms do not encounter (see, for example, Mezias, 2002). The primary sources and nature or the problems that conpanies face in foreign markets were first described in (Zaheer, 1995) as the concept of "liability of foreignness" (LOF). According to his theory, a company entering foreign markets incurs additional costs, similar to transactional ones, that domestic companies do not have. At the same time, the costs themselves are both ecohe same time, Russian companies are more likely to incur . A non-economic costs than economic ones (Panibratov, 2012)

Factors mitigating the negative impact of $\mathrm{LOF}$ effects include pillover-learning effects, savings due to the increasing scale of activities, the formation of specific business skills in different
aingerno conditions and the accumulation of experience in conducting international operations (Li, 1995).

The goal is to identify the effects of the "liability of foreignness" arising in the process of internationalization of Russian industrial companies in non-energy sectors.

In this case, the greatest interest in this study is the question of the impact of the country of origin effect on the internationalization of Russian companies and the definition of mechanisms to eutralize the effects of the country of origin.

For the first time, the concept of additional costs incurred by Hymer (Hymer, 1976), while using the term "Costs of doe business (Hrod" (CDBA) Hymer pesented these costs ofly as direct one-time financial costs, without addressing the problems of overcoming national barriers, the costs of adaptation to a new market (associated, for example, with a lack of knowledge about the market and experience).

For the first time the presence of the non-economic costs associated with internationalization and labeled as problem of LOF effects was written by (Zaheer, 1995), and was subsequently clarified as additional costs that can be incurred by a company operating abroad, compared to local firms due to the large distance between the parent company and the market where its units operate, and ignorance and lack of legitimacy in a foreign market Yu, Kim, 2010)

The causes and level of LOF effects are described in (Mezias, 1202, Eden, Miller, 2004). It provides strategies for overcoming (Zem and achieving competitive advantage in foreign markets ing on the industry and the level of development of the country of origin of the company and the host country is described in (Gaur Kumar, Sarathy, 2011).

Most researchers emphasize the fact that there are a large number of factors that influence the extent of the LOF effect (related to the characteristics of host countries and countries of origin, the sphere of activity and ownership structure) an make it difficult to accurately measure this effect and compare the LOF effect.

The causes of LOF effects are divided into two groups: those related to the internal characteristics of the company and the exThe characteristics of the company include the ability to learn, the availability of specific resources, ownership structure, etc. The second group of reasons may, in turn, contain two categories of characteristics: inherent in the country of origin and related to the receiving market. Since in this study the country of origin is unchanged (we consider the internationalization of only Russian firms), it is essential to study the diversity of the effect of the business en

The concept of country of origin for the first time the county was presented in the article of Schooler (Schooler, 1965) and is defined as "the country where the parent company is of origi which markets a product or brand" (Johansson, Douglas, Nondka 1985), and the production itself does not have to be located the same country. Therefore, the effect of the country of origin is often defined as "the degree to which the place of production affects the evaluation of the product" (Gurhan-Canli, Maheswaran 2000). Besides, there is a separate line of research that studies the effect of moving production from the country where the head office is located to another country on the company's brand image and consumer perception of product quality (Schweiger, Otter, Strebinger, 1997).

The influence of the country of origin of the company on its activities can manifest itself in the process of internationalization, the development of a new market, with a staff member, etc.

\section{Characteristics of a sample of innovatively active companies operating in foreign market}

\begin{tabular}{|c|c|c|c|c|c|c|c|}
\hline Company & $\begin{array}{l}\text { Field of } \\
\text { activity }\end{array}$ & $\begin{array}{l}\text { Export } \\
\text { share in } \\
\text { revenue, } \\
\text { \% }\end{array}$ & $\begin{array}{l}\text { Form of enter- } \\
\text { ing the foreign } \\
\text { market }\end{array}$ & $\begin{array}{c}\text { Number } \\
\text { of coun- } \\
\text { tries }\end{array}$ & $\begin{array}{c}\text { Region of pres- } \\
\text { ence }\end{array}$ & $\begin{array}{l}\text { Competitive advantages in the foreign } \\
\text { market }\end{array}$ & $\begin{array}{l}\text { R \& D costs, } \\
\text { \% of sales } \\
\text { revenue }\end{array}$ \\
\hline nonicol & $\begin{array}{l}\text { Roofing, } \\
\text { waterproofing } \\
\text { and heatin- } \\
\text { sulating } \\
\text { materials }\end{array}$ & 20 & $\begin{array}{l}\text { Export, subsid- } \\
\text { iary }\end{array}$ & 13 & Europe & 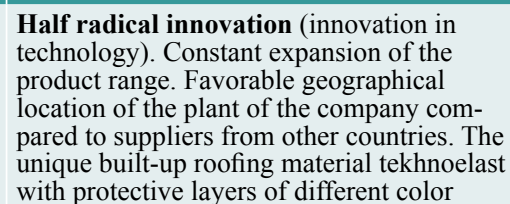 & 4 \\
\hline Global & $\begin{array}{l}\text { Oral Care } \\
\text { Products }\end{array}$ & 20 & $\begin{array}{l}\text { Export, subsid- } \\
\text { iary }\end{array}$ & 70 & $\begin{array}{l}\text { Europe, South- } \\
\text { East Asia, } \\
\text { Middle East, } \\
\text { Commonwealth of } \\
\text { Independent States } \\
\text { (CIS) countries }\end{array}$ & $\begin{array}{l}\text { Radicali innovation. Lack of analogues } \\
\text { develeped product in the world. Complete } \\
\text { restart of product recipes erery tho years. } \\
\text { Own innovative high-tech developments }\end{array}$ & $10-15$ \\
\hline $\begin{array}{l}\text { ing } \\
\text { nologies }\end{array}$ & Lighting & 15 & $\begin{array}{l}\text { Export, subsid- } \\
\text { iary }\end{array}$ & 23 & $\begin{array}{l}\text { Europe, South- } \\
\text { East Asia }\end{array}$ & 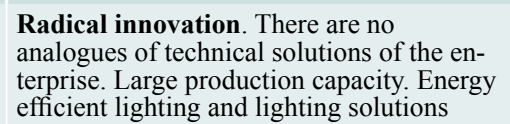 & 10 \\
\hline olu- & IT field & 18 & $\begin{array}{l}\text { Export, joint } \\
\text { venture }\end{array}$ & 5 & Europe & $\begin{array}{l}\text { Radical innovation. The development of } \\
\text { a revolutionary technology to significinantly } \\
\text { improve the efficiency of resuorre use } \\
\text { in real time . Network centric multiagent } \\
\text { system of coordinated management of } \\
\text { workshops }\end{array}$ & 17 \\
\hline & Building & 20 & $\begin{array}{l}\text { Export, subsid- } \\
\text { iary }\end{array}$ & 19 & $\begin{array}{l}\text { Europe, CIS } \\
\text { countries }\end{array}$ & $\begin{array}{l}\text { Radical innovation. Advanced innovative } \\
\text { technology, Production of non-traditional } \\
\text { products. Unique waterproofing material } \\
\text { penetron }\end{array}$ & 8 \\
\hline & Cosmetics & 10 & $\begin{array}{l}\text { Export, subsid- } \\
\text { iary }\end{array}$ & 35 & $\begin{array}{l}\text { USA, Europe, } \\
\text { Southeast Asia, } \\
\text { CIS countries }\end{array}$ & $\begin{array}{l}\text { Half radical innovation (innovation in } \\
\text { technology). Onn, unique in the territorial } \\
\text { location of the resoource base. A wide range } \\
\text { of products Reliable brand history. Natural } \\
\text { and organic cosmetics }\end{array}$ & 12 \\
\hline & $\begin{array}{l}\text { High-tech } \\
\text { equipment } \\
\text { for nuclear } \\
\text { facilities }\end{array}$ & 25 & $\begin{array}{l}\text { Export, subsid- } \\
\text { iary }\end{array}$ & 13 & $\begin{array}{l}\text { Europe, North } \\
\text { America, South- } \\
\text { East Asia }\end{array}$ & $\begin{array}{l}\text { Radical innovation. Production of exclu- } \\
\text { sive equipment based on effective innova- } \\
\text { tive technologies. Mlonitorin and control } \\
\text { systems of high radiation resistance }\end{array}$ & 15 \\
\hline $\begin{array}{l}\text { Metal } \\
\text { vare }\end{array}$ & $\begin{array}{l}\text { Manufacture } \\
\text { of metal } \\
\text { dishes }\end{array}$ & 7 & Export & 2 & CIS countries & $\begin{array}{l}\text { Radical innovation. Technologies to } \\
\text { producc products with the highest class of } \\
\text { safety for consumers }\end{array}$ & 1.3 \\
\hline & $\begin{array}{l}\text { Juice and } \\
\text { babyfood } \\
\text { production }\end{array}$ & 12 & Export & 8 & $\begin{array}{l}\text { Belarus, Kazakh- } \\
\text { stan, Kyrgyzstan, } \\
\text { China, Turkmen- } \\
\text { istan, Tajkistan, } \\
\text { Moldova, Ukraine }\end{array}$ & $\begin{array}{l}\text { Half radical innovation (innovation in } \\
\text { technology) Advanec development of its } \\
\text { own resource base. High technological } \\
\text { level of production (I-plant). Continuous } \\
\text { technological update }\end{array}$ & 21 \\
\hline & 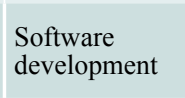 & 15 & Export & 4 & $\begin{array}{l}\text { Belarus, Kazakh- } \\
\text { stan, Kyrgyzstan, } \\
\text { China }\end{array}$ & $\begin{array}{l}\text { Radical innovation. Unique products } \\
\text { exceeding the power of foreign analogues }\end{array}$ & $8-10$ \\
\hline
\end{tabular}


(Yu, Zaheer, 2010). The results of many studies also indicate a strong correlation between the company's actions and the institutional environment of the country of origin (Deephouse, Such-

Mst of the traditional studies on the impact of the country of origin on the performance of companies analyze the perceptio wburry, 2012)

The effect of the country of origin may also vary depending on the category of goods or services associated with the country
of origin of their producer. Sometimes this phenomenon is defined as "product-country image" (Knight, Holdsworth, Mather, 2007)

\section{CHARACTERISTICS}

OF INTERNATIONALIZATION

STRATEGIES USED BY RUSSIAN

NON-ENERGY COMPANIES

To achieve the goal of the study, we selected 10 Russian inTheracts. Charac teristics of the companies are presented in Table 2 .

Among the selected companies, only $20 \%$ carry out their activities everywhere and develop due to foreign expansion, $30^{\circ}$ have an average level of internationalization, and $50 \%$ have low level. The main form of entry into foreign markets is export. Most companies used the "horizon expansion" strategy, i.e., promote products abroad that are successful in the domestic market. At the initial stage, the companies concentrated mainly on the purchase of imported components and for a long time linked the prospects of the development with the domestic market. Then As a

As an example, we can look at Splat Global. The company Having received recognition in the domestic market the company movel to the inter of exports. Now Splat Global owns more than 10 Russian and foreign patents that testify very high competitiveness of products on a global scale.

Many of the companies carried out a step-by-step model of internationalization: first, they made expansion to other regions of Russia (not internationalizing, but gaining experience in conducting operations in unfamiliar markets, forming specific competencies in the conditions of high competitive pressure and/or national characteristics of certain regions), then these companies penetrated the markets of the CIS countries and later into other countries. An example of this is a turn-based internationalization of Sady Pridonia, which is a food produce and specialize on juice and baby food production. After gaining exporting which until recently was limited by the CIS country markets. However in the recent past, deliveries of products to China began. The strategy of Sady Pridonia is aimed at the advanced development of its own raw material base and constant technological renewal. The company is among the firs in the world committed to the creation of I-plant system-fully automated production, which can be controlled by one person online.

Table
Most companies use such competitive advantages as technological leadership, leadership in the domestic market, whic

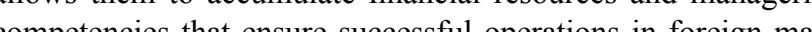
Table 3 presents the characteristics of the internationalization Since LOF sources are eqpanies.

equally related to the company's exronment, we combine the specific features Russian companies in the non-energy sector and the way they are internationalized in Table 4. At the same time, we rely on the theory of D. Dunning (Dunning, 2009), indicating the presence thee types of sources of competitive advantages: 1) specific esources and competencies; 2) regions of presence; 3) the way

5. CONCLUSIONS AND PRACTICAL APPLICATION OF RESEARCH RESULTS

Despite the limited size of the sample of companies, with some caution, the analysis carried out allows us to draw some strategy used by Russian companies in non-energy sectors. In most cases, companies use a replication strategy, which is to offer a standardized product in all countries. Some of the companies reviewed, use a strategy of limited adaptation of products by local company departments to local conditions. However, a absolute majority of companies strive to repeat the basic busines principles in each country or region of the world where it opeates. Another part of the surveyed companies uses a multi-loc strategy which inplies a concentration of core conpetencies of the corporation in the field of research and development, product development and marketing in the country parent company.
However, at the same time, companies adapt their products and services to the requirements and tastes of consumers in each che companis observe the al the form subsidiary Most of the reviewed companies prefer using a global stre-

yy i. , conduct operations in all countries of the world however, about a third of companies use the strategy of the region of basing or mastering only two regions, i.e., conduct operations or only in the region of basing or in two regions.

All this testifies to the initial stage of the internationalizatio of Russian companies in the non-energy sector, the tendency of companies to conduct simple operations in international markets, and the use of the least risky strategies of internationalization. Two-thirds of the companies reviewed use the strategy of innovation and branding, which implies continuous product development and the introduction of more modern versions of the product to the market. Companies try to take a position when other market participants are in a position to catch up with the comIt brins to the mal det products that have no world peers, whose export share is about $20 \%$ of the total revenue. Another example of such a strategy may become the Diakont, the share of revenues from export activities of which is more than $25 \%$. The company is a developer of high radiation resistance monitoring and control systems for nuclear power plants, and Diakont products are in demand among foreign customers - the world leaders in nuclea energy. It is successfully operating, demonstrating high reliability and, according to estimates, surpassing competitors' analogs.

Finally, most of the companies reviewed are focused on concentrating on network resources with an average level of overseas sales.

Thus, despite the unfavorable situation for internationalization, the lack of significant state support, which can be used by

\begin{tabular}{|c|c|c|c|c|c|c|c|}
\hline Company & $\begin{array}{l}\text { aracteristic } \\
\text { rategy for } \\
\text { rlett, Gos- } \\
\text { al, 2000) }\end{array}$ & $\begin{array}{l}\text { Characterization } \\
\text { of strategy by } \\
\text { (Jeannet, Hen- } \\
\text { nessey, 2004) }\end{array}$ & \begin{tabular}{|c|} 
Characteriza- \\
tion of strategy \\
by (Rugman, \\
Verbeke, 2004)
\end{tabular} & $\begin{array}{c}\text { Characterization } \\
\text { of strategy by (Fin- } \\
\text { kelstein, Harrevy, } \\
\text { Lawton, 2007) }\end{array}$ & \begin{tabular}{|l} 
Characteristics \\
of fhe strategy \\
for (Kotter, \\
Berger, Bikhoff, \\
2015)
\end{tabular} & \begin{tabular}{|} 
Characteristics \\
of the strategy \\
for (Knight, \\
Liesch, 2015)
\end{tabular} & \begin{tabular}{|l} 
Characteristics \\
of the strategy \\
for Cerrato,o, \\
Crosato, Deppe- \\
ru, 2016)
\end{tabular} \\
\hline onicol & & $\begin{array}{l}\text { eggy of } \\
\text { centric orien- } \\
\text { n }\end{array}$ & & & $\begin{array}{l}\text { Focused } \\
\text { lio strate }\end{array}$ & ing & $\begin{array}{l}\text { etwork } \\
\text { ise }\end{array}$ \\
\hline t-Glo & lica & $\begin{array}{l}\text { tegyof ethno- } \\
\text { ric orientation }\end{array}$ & Global strategy & & & & $\begin{array}{l}\text { etwc } \\
\text { ise }\end{array}$ \\
\hline $\begin{array}{l}\text { ting } \\
\text { inolc }\end{array}$ & & & Global & & & orn gl & \\
\hline it solutions & $\begin{array}{l}\text { Multilocal } \\
\text { strategy }\end{array}$ & & Global & & & orn g & $\begin{array}{l}\text { Network Enter- } \\
\text { prise }\end{array}$ \\
\hline on-Russia & $\begin{array}{l}\text { Multilocal } \\
\text { strategy }\end{array}$ & & Global : & & & & \\
\hline uraSiberica & & $\begin{array}{l}\text { of ethno- } \\
\text { rientation }\end{array}$ & Global strateg, & & & Born $\mathrm{g}$ & \\
\hline ront & & & c & & & Derab & \\
\hline $\begin{array}{l}\text { a Metal } \\
\text { eware }\end{array}$ & Renlication & ic orientation & & & portfo- & & \\
\hline ridonia & teg & & & & & & \\
\hline ntur & tegy & $\begin{array}{l}\text { tegy of ethno- } \\
\text { tric orientataion }\end{array}$ & strategy & & lio strategy & & \\
\hline
\end{tabular}

Table 4
Potential sources of LOF for Russiannon-energy exportingcompanies

\begin{tabular}{|c|c|c|c|}
\hline Company & Specificresources & $\begin{array}{l}\text { Internationalization- } \\
\text { method }\end{array}$ & Regions of presence \\
\hline Technonicol & $\begin{array}{l}\text { Favorable geographical location of the plant of the company } \\
\text { conpared to supphiers from other countries } \\
\text { The unique built-up roofing material technoelast with protective } \\
\text { layers of different color }\end{array}$ & Export, subsidiary & Europe \\
\hline Splat-Global & $\begin{array}{l}\text { Lack of analogues developed product in the world. Complete } \\
\text { restart of product receipes every two years. Own innovative high- } \\
\text { tech developments }\end{array}$ & Export, subsidiary & $\begin{array}{l}\text { Europe, South-East Asia,Middle East, } \\
\text { CIScountries }\end{array}$ \\
\hline Lighting Technologies & $\begin{array}{l}\text { There are no analogues of technical solutions of the enterprise. } \\
\text { Large production capacity }\end{array}$ & Export, subsidiary & Europe, South-EastAsia \\
\hline Smart solutions & $\begin{array}{l}\text { Netcentric multi-agent system for coordinated workshop man- } \\
\text { agement }\end{array}$ & Export, jointventure & Europe \\
\hline Penetron-Russia & Unique waterproofing material penetron & Export, subsidiary & Europe, CIS countries \\
\hline Natura Siberica & $\begin{array}{l}\text { Own, unique in the territorial location of the resource base. A } \\
\text { wide range of products. }\end{array}$ & Export, subsidiary & $\begin{array}{l}\text { USA, Europe, South-East Asia, CIS } \\
\text { countries }\end{array}$ \\
\hline Diakont & $\begin{array}{l}\text { Production of exclusive equipment based on effective innovative } \\
\text { technologies. } \\
\text { Monitoring and control systems of high radiation resistance }\end{array}$ & Export, foreign branch & $\begin{array}{l}\text { Europe, North America, South-East } \\
\text { Asia }\end{array}$ \\
\hline Neva Metal Tableware & $\begin{array}{l}\text { Technologies to produce products with the highest class of safety } \\
\text { for consumers }\end{array}$ & Export & CIS countries \\
\hline Sady Pridonia & $\begin{array}{l}\text { Advanne development of its own resource base. Hight techno- } \\
\text { logical level of production (I-plant). Continuous technological } \\
\text { update }\end{array}$ & Export & $\begin{array}{l}\text { Belarus, Kazakhhtan, Kyrgyzstan, } \\
\text { China, Turkmenintan, Tajikistan, } \\
\text { Moldova, Ukraine }\end{array}$ \\
\hline Kontur & Unique products exceeding the power of foreign analogues & Export & $\begin{array}{l}\text { Belarus, Kazakhstan, Kyrgyzstan, } \\
\text { China, }\end{array}$ \\
\hline
\end{tabular}


competitors in other countries, Russian innovative and active companies of non-energy sectors manage to use a number of competitive advantages: a reputation of technological superiority of the world level in specific industries, the capacity and com-
plexity of the domestic market to enter the most complex and promising markets.

According to the results of the study, several conclusions can be drawn regarding the impact of the "liability of foreignness" factor on the process of internationalization of Russian compafactor on the process of inter
nies in the non-energy sector

Concerning companies from emerging countries, it is critica for the effect of country of origin, which plays a part of the facto as a whole LOF and having a considerable weight for Russian companies in particular.

In this regard, the impact of the country of origin effect on the internationalization of Russian companies is determined by the industry in which these companies operate. The variety of economic and non-economic mechanisms that influence the country of origin allows them to compensate for the impact on each other, as for example, in the case of overcoming the adverse effect caused ization of Russian companies in the non-resource sector, a postive effect associated with the reliability and high quality of the products and services. The positive effects of the country of theirin are determined by the existence of appropriate competitive advanages that help Russian companies to overcome the LOF effect. Thus, the identification of the sources of advantages of Russian firms and their development in the process of internationalization is a way to minimize the negative consequences of the liability of foreignness and the effects associated with their country of origin.

\section{АИТЕРАТУРА}

Алексанян А.А. (2014). Положительное и негативно влияние международной деятельности российских ТНК на национальную экономику // Экономика и предпринимательство. №6 6 (47). С. 74-76,

- Бухвалов А.В., Алексеева О.А. (2015). Стратегии международных компаний на развивающихся рынках: влиРоссийский журнал менеджмента. Т. 13. №2. С. 149-170. Катькало В.С., Медведев А.Г. (2011). Интернационализация российских компанй и. (ооффигурация их деловых -

(1) мй в условиях их интернационализа-

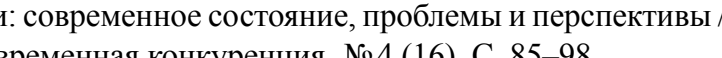

Проснуться экс о Эксперт. № 13. С. 15 .

- Уваров В.В. (2013). Стратегия интернационализаци как инструмент совмещения задач догоняющего и опережающего развития // Российский внешнеэкономический вестник. № 9. С. 3-14,

Широкова Г.В., Цуканова Т. В. (2013). Выход на международный рынок российских фирм малого и среднего ная конкуренщия. № 3 (39). С. $50-63$.
8. Harzing A.-W. (2000). An empirical test and extension of the Barlett and Ghoshal typology of multinational companies // Journal of International Business Studies. Vol. 31, N 1. P. Bal- (2010). Ov/palgrave.jbs.849081.

Barnard H. without Strong Firm Capabilities - The Value of Marketbased Resources // Journal of International Management.
Vol. 16, N 2 P. P. 165-176. DOI: https://doi.org/10.1016/j. intman.2010.03.007.

10. Cerrato D., Crosato L., Depperu D. (2016). Archetypes of SME internationalization: A configurational approach International Business Review 25 (1, part B). P. 286-295 DOI: https://doi.org/10.1016/j.ibusrev.2015.05.010.

11. Collinson S., Rugman A.M. (2007). The Regiona Character of Asian Multinational Enterprises // Asia Pacific Journal of Management. Vol. 24, N 4. P. 429-446. DOI: 10.1007/s10490-006-9035-

12. Deephouse D.L., Suchman M.C. (2008). Legitimacy in Organizational Institutionalism // The SAGE Handbook of Organizational Institutionalism/Eds.C. Oliver, K. Sahlin, D. emirbag M. Tato $\mathrm{E}$, Ghister K.W. (2009).

based Entry Modes of Emerging Co. W. (2009). EquityLessons from Turkey // Journal of World Business. Vol 44 $\mathrm{N}$ 4. $\quad \mathrm{P}$ 445-462 $\quad$ DOI: https://doi.org $/ 10.1016 / \mathrm{j}$ jwb.2008.11.009.

14. Denk N., Kaufmann L., Roesch J.-F. (2012). Liabilities of Foreignness Revisited: A Review of Contemporary Studie and Recommendations for Future Research // Journal of International Management. Vol. 18. P. 322-334. DOI https://doi.org/10.1016/j.intman.2012.07.001

15. Dunning J.H. (2009). Location and the Multinationa Enterprise: John Dunning's Thoughts on Receiving the Journal of International Business Studies 2008 Decade Award // Journal of International Business Studies. Vol. 40, N 1.P. 20-34. DOI: $10.1057 /$ jibs.2008.75.

16. Eden L., Miller S.R. (2004). Distance Matters: Liability of Foreignness, Institutional Distance and Ownership Strategy 221.

17. Gammeltoft P., Filatotchev I., Hobdari B. (2012). Emerging Multinational Companies and Strategic Fit: A Contingency Framework and Future Research Agenda // European Management Journal. Vol. 30. N 3. P. 175-188. DOI 10.1016/j.emj.2012.03.007.

18. Gaur A.S., Kumar V., Sarathy R. (2011). Liability of Foreignness and Internationalisation of Emerging Market Firms // Advances in International Management. Vol. 24. P. 211-233. DOI: $10.1108 / \mathrm{S} 1571-5027$ (2011) 0000024016. Gurhan-Canli Z., Maheswaran D. (2000). Cultural Variation in Country of Origin Effects // Journal of Marketing
Research. Vol. 37, N 3. P. 309-317. Hymer S. H. (1976). The Int

Naid National Firms: A Study of Foreign Direct Investment. Jeanet J-P. Hencey H. (2004).

(2004). Global Marketing Strategies. Boston: Houghton Mifflin. 613 p.

Johansson J.K., Douglas S.P., Nonaka I. (1985). Assessing
A New Methodological Perspective // Journal of Marketin Research. Vol. 22. P. 388-396. DOI: https://doi.org/10.1177 1002224378502200404

23. Knight J.G., Holdsworth D.K., Mather D.W. (2007) County-of-Origin and Choice of Food Imports: An In. Journal of International Business Studies. Vol. $38, \mathrm{~N}$. P. 107-125. DOI: 10.1057 / palgrave.jibs. 8400250 .

24. Knight G.A., Liesch P.W. (2015). Internationalization: From incremental to born global // Journal of World Business. Vo. 51, N 1. P. 93-102. DOI: 10.1016/j.jwb.2015.08.011.

25. Kotler P., Berger R., Bickhoff N. (2010). The quintessence of strategic management: What you really need to know to survive in business. Springer Berlin Heidelberg. 133 p. DO https://doi.org/10.1007/978-3-642-14544-5.

26. Li J. (1995). Foreign Entry and Survival: Effects of Strategic Choices on Performance in International Markets // Strategic Management Journal. 1995. Vol. 16, N 5. P. 333-351. DO https://doi.org/10.1002/smj.4250160502.

27. Luo Y.D., Tung R.L. (2007). International Expansion of Emerging Market Enterprises: A Springboard Perspective N. P. 481-498. DOI: https://doiorg/10.1057/palgave. jibs. 8400275 .

28. Mezias J.M. (2002). How to Identify Liabilities of Foreignness and Assess Their Effects on Multination Corporations // Journal of International Management 2002. Vol. 8. P. 265-282. DOI: https://doi.org/10.1016/S10754253(02)00069-8

29. Mihailova I., Panibratov A. (2012). Determinants of Internationalization Strategies of Emerging Market Firms: A Multilevel Approach // Journal of East-West Business. Vol. 18. N 2. P. 157-184. DOI: $10.1080 / 10669868.2012 .709922$.

30. Newburry W. (2012). Waving the Flag: The Influence of Country of Origin on Corporate Reputation // The Oxford Handbook of Corporate Reputation / Eds. T. G. Polloc, DOI: 10.1093/oxfordhb/9780199596706.013.0012.

31. Panibratov A. (2012). Russian Multinationals: From Regional Supremacy to Global Lead. London, N. Y. Routledge.

32. Ramamurti R. (2009). What Have we Learned about Emerging-Market MNEs? // Emerging Multinational in Emerging Markets / Eds.R. Ramamurti, J.V. Singh. Cambridge, UK: Cambridge University Press. P. 399-426. DOI: https://doi.org/10.1017/CBO9780511576485.013.

\section{REFERENCES}

1. Aleksanyan, A. A. (2014). Polozhitelnoe i negativnoe vliyanie mezhdunarodnoj deyatelnosti rossijskikh TNK na nacionalnuyu ehkonomiku // Ekonomika i predprinimatelstvo 6 (47):74-76 [Aleksanyan, A. A. (2014). Positive and negative impact of the international activities of Russian TNC on the national economy. Economy and Entrepreneurship. 6 (47):74-76. (In Russ.).]

Bukhvalov, A. V., Aluksera, O. A. (2015). Strategii mezhdunarodnykh kompanij na razvivayushchikhsya rynkakh vli-
33. Rugman A.M. (2005). The Regional Multinationals: MNEs and "Global" Strategic Management. Cambridge, UK Cambridge University Press. 276 p. DOI: https://doi.org/

34. Rugman A., Verbeke A. (2004). A Perspective on regional Bus Studies. 35 (1): 3-18. DOI: 10.1057 /p totionave. jibs.8400073.

35. Schooler R.D. Product Bias in the Central American Common Market //Journal of Marketing Research. 1965. Vol. 2. N 4. P. 394-397.

36. Schweiger G., Otter T., Strebinger A. (1997). The Influence of Country of Origin and Brand on Product Evaluation an the Implications thereof for Location Decisions // CEMS Business Review. Vol. 2. N 1. P. 5-26

37. Trachuk A., Linder N. (2018). Learning-by-exporting effects on innovative performance: Empiric study results Knowledge Management Research \& Practice. Vol. 16, N 2. P. 220-234. DOI: https://doi.org/10.1080/14778238.2018.

38. Trachuk A., Linder N. (2018). Innovation and Performance An Empirical Study of Russian Industrial Companie Managent Vol.15, N 3. 1850027. DOI: https://doi org/1 $0.1142 / \mathrm{S} 021987701850027 \mathrm{X}$

39. Tseng C.H., Tansuhaj P., Hallagan W. et al. (2007). Effects of firm resources on growth in multinationality // Journa of International Business Studies. Vol. 38, N 6. P. 961-974. DOI: $10.1057 /$ palgrave.jibs. 8400305 .

40. Yu J., Kim S.S. (2010). Liability of Foreignness and the Growth of an Industry: A Dynamic Approach // Academy of Management Annual Meeting Proceedings. P. 1-6.

1. Yu J., Zaheer S. (2010). Building a Process Model of Local Adaptation of Practices: A Study of Six Sigma Implementation in Korean and US Firms // Journal of International Business Studies. Vol. 41. P. 475-499. DO

2. Zaheer S. (1995). Overcoming the Liability of Foreignnes DOI: $10.2307 / 256683$.

43. Zimmermann J. (2008). Overcoming the Inherent Sources of Liability of Foreignness: Measuring and Compensating the Disadvantage of Being Foreign: Doctoral Thesis. Augsburg: Wirtschaftswissenschaftliche Fakultät, Universität Augsburg.

yanie globalizacii i opyt lokalizaciı proizvodstva// Rossijskij zhurnal menedzhmenta. 13 (2).149-170. [Bukhvalov, A. V. Alekseeva, O. A. (2015). Strategies of international companies in emerging markets: Impact of globalization and experience of localization. Russian Management Journal. 13(2):149-170. (In Russ.).

. Katkalo, V. S., Medvedev, A. G. (2011). Internacionalizaciya rossijskikh kompanij i konfiguraciya ikh delovykh operacij $/$ Vestnik S.Pet burgkogo universitet. Ser. Mend 
2:7-38. [Katkalo, V. S., Medvedev, A. G. (2011). Internationalisation of Russian firms and configuration of their value chain. Bulletin of the University of St. Petersburg. Management. 2:7-38. (In Russ.).

Lukashenko, E. A. (2009). Konkurentosposobnost rossi-
jskikh predpriyatij v usloviyakh ikh internacionlizaci jskikh predpriyatij $v$ usloviyakh ikh internacionalizaci mennaya konkurenciya. 4(16):85-98. [Lukashenko, E. A. (2009). Competitiveness of Russian enterprises in the conditions of internationalization: current state, problem conditions of internationalization: current state, problems
and perspectives. Modern competition. 4(16):85-98. (In Russ.).].

5. Prosnutsya eksporterom: Redakcionnaya statya (2015). Ekspert. 13:15. [Wake up exporter: Editorial (2015). Expert. (13):15. (In Russ.).]

6. Uvarov, V. V. (2013). Strategiya internacionalizacii kak instrument sovmeshcheniya zadach dogonyayushchego operezhayushchego razvitiya // Rossijskij vneshneekonomicheskij vestnik. 9:3-14. [Uvarov, V. V. (2013). Internationalization strategy as a tool for combining the tasks of catching up and advancing

Shirokova, G. V. Cukanova, T. V. (2013). Vykhod mezhdunarodnyj rynok rossijskikh firm molo i sedngo biznesa integrativnyj podkhod $\mathrm{k}$ analizu // Sovremennaya konkurenciya. 3 (39):50-63. [Shirokova, G. V. Tsukanova, T. V. (2013). Entry into the international market of Russian small and medium-sized businesses: an integrative approach to analysis. Modern Competition. 3 (39):50-63

8. Barnard, H. (2010). Overcoming the Liability of Foreignness without Strong Firm Capabilities - The Value of Market-based Resources. Journal of International Management. 16(2):165-176. DOI: https://doi.org/10.1016/j. intman.2010.03.007

. Cerrato, D., Crosato, L., Depperu, D. (2016). Archetypes of SME internationalization: A configurational approach. In ternational Business Review. 25 (1, part B):286-29
https://doi.org/10.1016/j.ibusrev.2015.05.010.

10. Collinson, S., Rugman, A. M. (2007). The Regional Charac-
ter of Asian Multinational Enterprises. Asia Pacific Journal ter of Asian Multinational Enterprises. Asia Pacific Journal of Managen

11. Deephouse D. L., Suchman M.C. (2008). Legitimacy in Organizational Institutionalism. In: The SAGE Handbook of Organizational Institutionalism, eds. C. Oliver, K. Sahlin, R. Suddaby. Greenwood. Oxford: Sage. 49-77.

12. Demirbag, M., Tatoglu, E., Glaister, K. W. (2009) Equity-based Entry Modes of Emerging Country MultinaVol. 44, N 4. P. 445-462. DOI: https://doi.org/10.1016/j. jwb.2008.11.009.

13. Denk N., Kaufmann, L., Roesch, J.-F. (2012). Liabilities of Foreignness Revisited: A Review of Contemporary Studies and Recommendations for Future Research. Journal of org/10.1016/j.intman.2012.07.001.

4. Dunning, J. H. (2009). Location and the Multinational Enterprise: John Dunning's Thoughts on Receiving the Journa of International Business Studies 2008 Decade Award. Jour- nal of International Business Studies. 40 (1):20-34. DOI:

10.1057/jibs.2008.75.
15. Eden, L., Miller, S. R. (2004). Distance Matters: Liability of Foreignness, Institutional Distance and Ownership Strategy
Advances in International Management 16:187-221 Gest. P. Find Management. 16.187-221.

ing Multintional Companies and Strategic Fit: A Contingency Framework and Future Research A Fit: A ContinManagement Journal. 30(3):175-188. DOI: 10.1016/j. emj.2012.03.007.

17. Gaur, A. S., Kumar, V., Sarathy, R. (2011). Liability of Foreignness and Internationalisation of Emerging Market Firms. Advances in International Management. 24:211-233. DOI 10.1108/S1571-5027 (2011) 0000024016.

18. Gurhan-Canli, Z., Maheswaran, D. (2000). Cultural Variations in Country of Origin Effects. Journal of Marketing Research. 37(3):309-317.

19. Harzing A.-W. (2000). An empirical test and extension of the Barlett and Ghoshal typology of multinational companies. Journal of International Business Studies. 31(1):10119. Dol: 10. J. (1976). The Jus.84081.

ingerations of $\mathrm{Na}-$ . (

. Jeannet, J.-P., Hennessey, H. (2004). Global Marketing Strategies. Boston: Houghton Mifflin. $613 \mathrm{p}$

22. Johansson, J. K., Douglas, S. P., Nonaka, I. (1985). Assessing the Impact of Country-of-Origin on Product Evaluations: A New Methodological Perspective. Journal of Marketing Research. 22:388-396. DOI: https://doi.org/10.1177/00222 4378502200404

23. Knight, J. G., Holdsworth, D. K., Mather, D. W. (2007) County-of-Origin and Choice of Food Imports: An In-depth Study of European Distribution Channel Gatekeepers. Jour nal of International Business Studes. 38(1):107-125. DOI 10.1057/palgrave.jibs. 8400250

4. Knight, G. A., Liesch, P. W. (2015) Internationalization: From incremental to born global. Journal of World Business.

Kotler, P., Berger, R, Bickhoff, N. (2010). The

of strate survive in business. Berlin; Heidelberg: Springer. $133 \mathrm{p}$. DOI: https://doi.org/ 10.1007/978-3-642-14544-5.

26. Li, J. (1995). Foreign Entry and Survival: Effects of Strategic Choices on Performance in International Markets. Strategic Management Journal. 16(5):333-351. DOI: https:// doi.org/10.1002/smj.4250160502.

27. Luo, Y. D., Tung, R. L. (2007). International Expansion of Emerging Market Enterprises: A Springboard Perspective. Journal of International Business Studies. 38(4):481-498. DOI. https.//doi.org/10.1057/palgrave.jibs.8400275.

28. Mezias, J. M. (2002). How to Identify Liabilities of Foreignness and Assess Their Effects on Multinational CorpoDOI: https://doiog/10.1016/S1075-4253(02)00069-8.

9. Mihailova I., Panibratov A. (2012). Determinants of

ternationalization Strategies of Emerging Market Firms: A Multilevel Approach. Journal of East-West Business. 18 (2):157-184. DOI: $10.1080 / 10669868.2012 .709922$.
30. Newburry W. (2012). Waving the Flag: The Influence of country of Origin on Corporate Reputation. In: The Oxford Handbook of Corporate Reputation, eds. T. G. Polloc, M.L. Barnett. Oxford: Oxford University Press. $240-2$
DOI: 10.1093/oxfordhb/9780199596706.013.0012.

31. Panibratov, A. (2012). Russian Multinationals: From ReDo ledge.

32. Ramamurti, R. (2009). What Have we Learned about Emerging-Market MNEs? In: Emerging Multinationals i Emerging Markets, eds. R. Ramamurti, J.V. Singh. Cambridge, UK: Cambridge University Press. P. 399-426. DOhttps://doi.org/10.1017/CBO9780511576485.013.

33. Rugman, A. M. (2005). The Regional Multinationals: MNE and "Global" Strategic Management. Cambridge, UK: Canbridge University Press. 276 p. DOI: https://doi.org/10.10

34. Rugman, A., Verbeke, A. (2004). A Perspective on regional and global strategies of MNEs. Journal of International Business S
jibs 8400073 .

35. Schooler, R. D. (1965). Product Bias in the Central American Common Market. Journal of Marketing Research. 2(4):394-397.

36. Schweiger, G, Otter, T., Strebinger, A. (1997). The Influence of Country of Origin and Brand on Product Evaluation and the Implications thereof for Location Decisions. CEMS Business Review. 2(1):5-26.
37. Trachuk, A., Linder, N. (2018). Learning-by-exporting effects on innovative performance: Empiric study results. Knowledge https://doi.org/10.1080/14778238 2018.1439675.

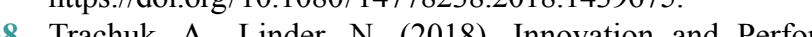
mance: An Empirical Study of Russian Industial Compnies. International Journal of Innovation and Technolog Management 15(3):1850027. DOI: https://doiorg/10.1142 /S021987701850027X

39. Tseng, C. H., Tansuhaj, P., Hallagan, W. et al. (2007). Effects of firm resources on growth in multinationality. Journal of International Business Studies. 38(6):961-974. DOI 10.1057/palgrave.jibs. 8400305

40. Yu, J., Kim, S. S. (2010). Liability of Foreignness and the Growth of an Industry: A Dynamic Approach. Academy of Management Annual Meeting Proceedings. P. 1-6.

1. Yu, J., Zaheer, S. (2010). Building a Process Model of Local Adaptation of Practices: A Study of Six Sigma Implementation in Korean and US Firms. Journal of International Business Studies. 41.475-499.

Zator, S. (1995). Overconi

coming the Liability of Foreignness. Academy of Management Journal. 38:341-363. DOI $10.2307 / 256683$

43. Zimmermann, J. (2008). Overcoming the Inherent Sources of Liability of Foreignness: Measuring and Compensating the Disadvantage of Being Foreign. Doctoral Thesis. Augsburg: Wirtschaftswissenschaftliche Fakultät, Universität Augsburg.

\section{ABOUT THE AUTHOR}

\section{Gaik G. Nalbandyan}

Postgraduate student, assistant, Department of Management, Financial University under the Government of the Russian Federation. Research intere

E-mail: GGNalbandyan@fa.ru

\section{ИНФОРМАЦИЯ ОБ АВТОРЕ}

Г. Г. Налбандян

Аспирант Департамента менеджмента, ассистент ФГОБУ ВО «Финансовый университет при Правительстве Российской Федерации». Область научных интересов: стратегии развития промышленных компаний,

межфирменное сотрудничест 